\title{
IAMJ
}

INTERNATIONAL

AYURVEDIC

MEDICAL JOURNAL

\section{ROLE OF HEMANT RITU (EARLY WINTER) FOR MAINTEINANCE AND ENHANCEMENT OF BALA (STRENGTH)}

\author{
Shilpa Kachhawaha ${ }^{1}$, Rajesh Kumar Sharma ${ }^{2}$, Dinesh Chandra Sharma ${ }^{3}$ \\ ${ }^{1}$ P.G. Scholar, P.G. Department of Kriya Sharir, DSRRAU, Jodhpur, Rajasthan, India \\ ${ }^{2}$ Professor \& H.O.D., P.G. Department of Kriya Sharir, DSRRAU, Jodhpur, Rajasthan, India \\ ${ }^{3}$ Associate professor, P.G., Department of Kriya Sharir, DSRRAU, Jodhpur, Rajasthan, India
}

Corresponding Author: mohitparihar84@gmail.com

https://doi.org/10.46607/iamj09042021

(Published Online: April 2021)

Open Access

(C) International Ayurvedic Medical Journal, India 2021

Article Received: 26/03/2021 - Peer Reviewed: 31/03/2021 - Accepted for Publication: 31/03/2021

Check for updates

\begin{abstract}
Seasons (Ritus) are the inherent global earth clock and the rhythm of the world. As per Ayurveda year is divided into six seasons, in which three season Shishira, Vasanta and Greeshma are known as Aadanakala. Other three seasons Varsha, Sharad and Hemanta are said to be Visargakala. In Visarga kala, as the Sun is located in southwards position, its heat reduces or slows down due to the effect of time and its position with respect to the Earth, wind, cloud and rain. The power of the Moon is predominant. Rainwater decreases the heating effect of nature. All of these lead to the predominance of non-dryunctuous, amla (sour), lavana (salty), and madhura (sweet) rasa respectively and step by step rise of body strength in human beings during these three seasons. Out of all the Ritus, Hemanta Ritu is a unique Ritu in terms of having uttam bala. Falling in Dakshinayana, moon is very powerful than sun, Madhur rasa is predominant in this Ritu, so the strength (Bala) of person enhances during this period. This article focuses to disclose thorough review of literature of Hemant ritucharya and its implication towards maintenance and enhancement of Uttam Bala. In Ayurveda oja, veerya, prana, kapha etc terms are considered as synonyms of Bala. Besides prakruti(genetic), sara(physiological) and aahar(diet), kala (season) is one of the prime factors to govern the Bala of the person. Bala stands for the strength of the body in terms of physical, mental, immunological and resistance to the body, the word Bala is being used in different contexts to denote various aspects accordingly.
\end{abstract}

Keywords: Visarga kala, Hemant ritu, Bala 


\section{INTRODUCTION}

Ritu means (season) and Charya means (guidelines), it is a seasonal guideline for living healthy life, according to our Acharyas movement of sun is responsible for the different types of Ritu (season), this divides year into two Ayans and each Ayan comprises of three Ritus, which gives a total of 6 seasons in a year. Each season lasts for two months and these seasons are precisely found in Indian subcontinent. The two Ayans are Uttarayan and Dakshinayana depending upon the direction of the movement of the sun. In Uttarayan sun takes north way course and is said to be Aadankala (Shishira, Vasanta and Greeshma) because sun takes away the strength of the people and in Dakshinayana sun follows south way course and is said to be Visarga kala because power of the moon is more in this kala so it gives strength to the people. In human body same seasonal pattern exist. The seasons in the external world exist because of air, solar, and lunar system. Likewise, the internal air, solar and lunar system known as vata, pitta, kapha respectively, shows the same events and maintain the internal atmosphere (Homeostasis) in the body ${ }^{1}$. For living healthy life, the balanced state of all these Doshas are essential. Similarly, for the longevity of life maintenance of Bala is also necessary. The equilibrium state of this Bala is surely affected by seasons (Ritus). Ayurvedic classics defines about seasonal variation of the strength. In the starting of Visarga kala(varsha) and at the end of Adana kala (greeshma), human beings on the Earth have less Bala experience debility. In the middle of these two periods that is in sharad and vasanta, humans have madhyam Bala possess medium strength. At the end of the visarga kala(hemant) and at the beginning of adana kala (sheeshir) the strength in human beings is maximum that is uttam Bala. ${ }^{2}$

\section{Concept of Bala As Per Ayurveda}

Strength of mind body and its components is said to be bala. According to Sushruta, "Bala" is defined as "the factor due to which one obtains the nourishment and stability of Mamsa dhatu (the muscular tissues of the body), ability to perform various tasks efficiently, good complexion, clearness and pleasantness of voice along with clear and efficient working of all the organs either external like Gyaanendriya (sense organs) or Karmendriya (organs with motor functions) and internal like Manas (mind), Aatma (spirit). ${ }^{3}$ Bala also refers to prakrut kapha which is responsible for strengthening and lubrication of the body. ${ }^{4}$ One more synonym of bala as per Ayurveda is $O j a^{5}$, defined as the nectar of all the dhatus. It can be said as bioenergy that helps in sustaining the life and for nurturing the immune system of the body in normal state. Acharya Charaka classifies Bala as three types namely Sahaja, Kalaja and Yuktikrita. Among the three, Kalaja type is explained as the bala developed due to seasonal variations. ${ }^{6}$

\section{Concept of Hemant Ritu As Per Ayurveda}

According to Hindu calendar Margashirsha(saha) and Pausha (sahasya) forms Hemanta Ritu. As per English calendar, Hemanta Ritu starts from nov15 to jan15. The month of November begins with the gradually dropping temperature that makes way for Hemant Ritu, the early winter season. As per Ayurveda, Hemant Ritu begins with Sharad Purnima and it continues for two months, during which the earth cools down, giving rise to an energy that makes us feel rejuvenated. Some special changes occur in the environment and in our body during this season which is responsible for the development and enhancement of Uttam Bala in our body as follows: Due to atmospheric cold, the heat of the body is trapped inside the body(like in a closed chamber) due to vasoconstriction and gets obstructed from flowing outward, that leads to increase of Jatharagni (digestive fire). If this physiological action of the body doesn't occur it will causes death due to excessive cold. ${ }^{7}$ This provoked agni is capable of digesting the food which is inherently heavy (dravya guru) and in excess quantity (matra guru) and this properly digested food will surely nourishes the sapta dhatus successively will enhance the bala of the body. So if adequate heavy food is not consumed, it will burn away the Rasadi dhatus, as the food in the form of fuel is not available and it in turn will lead to 
aggravation of vata dosha. ${ }^{8}$ As described earlier bala is equivalent to prakrut kapha and in this ritu accumulation of kapha takes place in the body, ${ }^{9}$ this accumulated (sanchita) kapha is surely one of the reason for developing uttam bala in this season. Another reason for shreshth bala is the dominance of Madhur rasa, overwhelming Mahabhutas are Prithivi and Apa in Hemant ritu. As said in our classics from birth Madhur rasa is satmya (adapted or habituated) for the body and it gives strength to the

rasadi sapta dhatus ${ }^{10}$ this in turn will lead to increase in oja (the essence of all the dhatus) and is very essential vital component of our body and as said by acharya Sushrut oja is the karana and bala is its karya, accordingly this oja will tend to cultivate and enhance bala (strength) in the body ${ }^{11}$. Hence in this way superiority of Madhur rasa in this ritu induces uttam bala in the body.

All these above-described factors are responsible for generating Shreshta Bala in Hemant ritu and to maintain this strength in the body one should follow the seasonal regimen. Ayurveda prescribes specific foods, exercise, and lifestyle changes suited to the season. This process is called as Ritucharya.

Do's of Hemant Ritucharya (Diet and Lifestyle) ${ }^{12}$

* Unctuous, Sweet (madhur), sour(amla) and salt (lavana) food items should be consumed predominantly.

* Meat of fatty, aquatic and marshy animals should be taken. Meat of burrowing animals and roasted meat of animals that eat by snatching the prey should be consumed

* Drinking of madira and sidhu type of wines are advised.

* Dairy foods like cow milk, butter, ghee, edible oils and new rice are recommended.

* Drink lukewarm water throughout the season.

* Include honey in your diet.

* Have warm soups regularly.

* Consume sugar cane juice and sugar, jaggery, khand as these provide abundant energy.

* Abundance of healthy fruits and vegetables like Amla, fig, apple, lemon, raisins, spinach, pumpkin, carrots etc. should be consumed.
* In hemanta ritu, abhyanga (massage), utsadana (anointing), murdhni taila (applying oil on the head), fomentation by jentaka (a type of fomentation/sudation) method, sunbath, spending time in hot underground houses and warmer, inner rooms of the house, regular use of shoes is indicated.

* In winter season, vehicles, beds and seats should be well covered and spread over with thick quilts, deer or tiger skins, silken sheets, gunny-cloth sheets or blankets.

* Always wear thick and warm clothes and the body should be anointed with thick paste of Aguru (Eagle wood)

Don'ts of Hemant Ritucharya: At the beginning of winter season intake of food and drinks that cause vata vitiation and inherently light to digest in property(like udmantha), getting exposed to strong winds, sleeping in daytime, inadequate quantities of food, and intake of diluted gruel are contraindicated. ${ }^{13}$

\section{CONCLUSION}

Human being function like a microcosm of the universe and the physiological changes are predominantly affected by the changes in macrocosm e.g., geothermal changes due to the Sun or the effects of the Moon and other celestial bodies. The rotation of the Earth around the Sun and rotation of Moon around the Earth result in changes in season. The Sun is responsible for temperature variations on Earth and this leads to changes in the physical and mental strength of microcosm. ${ }^{14}$ As changes in the environment affect our body, it is very important for our body to get familiar with these changes. The Bala of a person varies according to change in seasons. Bala i.e. Strength is the ability of the body to do the activities and it also provide resistance to disease and boost the immune system. Hemant ritu plays an important role for developing uttam bala in the body. Bala of body depends on excellence of all dhatus and they all are produced by the action of agni on food. In Hemant ritu, agni is the strongest and is responsible for proper digestion. Food consumed is digested 
properly with the help of jatharagni to produce good ahar rasa which when administered through Dhatwagni leads to formation of good rasadi dhatu. Accumulation of Kapha takes place in this season. Kapha dosha is Bala of body \& the principal element of kapha are Prithvi and Jala. Regarding bala, prithvi represents sthiratva (stability), gurutva (heaviness and bulky) while Jala provides nourishment. Hemant ritu has predominancy Madhur rasa, this rasa itself described as strength promoting property. Hence wise man should adopt strictly regimens of Hemant ritu to regain perfect and sound health as this ritu is endowed with uttam bala.

\section{REFERENCES}

1. Sushruta Samhita part I, Hindi Commentary Ayurved Tattva Sandipika by Kaviraja Ambikadutt Shastri, Chaukhambha Sanskrit Sansthan, Varanasi, Reprint2018 Sutrasthana- 21/8.

2. Charak Samhita, Hindi Commentary Charak Chandrika by Dr.Brahmanand Tripathi, Chaukhambha Surbharti Prakashan, Varanasi, Reprint-2006 Sutrasthana-6/8.

3. Sushruta Samhita part I, Hindi Commentary Ayurved Tattva Sandipika by Kaviraja Ambikadutt Shastri, Chaukhambha Sanskrit Sansthan, Varanasi, Reprint2018 Sutrasthana- 15/25.

4. Charak Samhita, Hindi Commentary Charak Chandrika by Dr.Brahmanand Tripathi, Chaukhambha Surbharti Prakashan, Varanasi, Reprint-2006 Sutrasthana-17/117.

5. Sushruta Samhita part I, Hindi Commentary Ayurved Tattva Sandipika by Kaviraja Ambikadutt Shastri, Chaukhambha Sanskrit Sansthan, Varanasi, Reprint2018 Sutrasthana- 15/24.

6. Charak Samhita, Hindi Commentary Charak Chandrika by Dr. Brahmanand Tripathi, Chaukhambha Surbharti Prakashan, Varanasi, Reprint-2006 Sutrasthana-11/36.

7. Charak Samhita, Hindi Commentary Charak Chandrika by Dr. Brahmanand Tripathi, Chaukhambha Surbharti Prakashan, Varanasi, Reprint-2006 Sutrasthana-6/9,150.

8. Charak Samhita, Hindi Commentary Charak Chandrika by Dr.Brahmanand Tripathi, Chaukhambha Surbharti Prakashan, Varanasi, Reprint-2006
Sutrasthana-6/10.

9. Ashtang Hrdayam of Srimad Vagbhat, Hindi Commentary Nirmala by Dr.Brahmanand Tripathi, Chaukhambha Sanskrit Pratishthan, Delhi, , Reprint2007 Sutrasthana-12/24

10. Ashtang Hrdayam of Srimad Vagbhat, Hindi Commentary Nirmala by Dr.Brahmanand Tripathi, Chaukhambha Sanskrit Pratishthan, Delhi, , Reprint2007 Sutrasthana-10/7

11. Sushruta Samhita part I, Hindi Commentary Ayurved Tattva Sandipika by Kaviraja Ambikadutt Shastri, Chaukhambha Sanskrit Sansthan, Varanasi, Reprint2018 Sutrasthana- 15/

12. Charak Samhita, Hindi Commentary Charak Chandrika by Dr. Brahmanand Tripathi, Chaukhambha Surbharti Prakashan, Varanasi, Reprint-2006 Sutrasthana-6/11-17.

13. Charak Samhita, Hindi Commentary Charak Chandrika by Dr. Brahmanand Tripathi, Chaukhambha Surbharti Prakashan, Varanasi, Reprint-2006 Sutrasthana-6/18.

14. https://www.carakasamhitaonline.com/index.php/Tasy ashiteeya_Adhyaya

\section{Source of Support: Nil Conflict of Interest: None Declared}

How to cite this URL: Shilpa Kachhawaha et al:Role Of Hemant Ritu (Early Winter) For Mainteinance And Enhancement Of Bala (Strength). International Ayurvedic Medical Journal \{online\} 2021 \{cited April, 2021\} Available from: http://www.iamj.in/posts/images/upload/829 832.pdf 